American Journal of Agricultural and Biological Sciences 6 (4): 549-552, 2011

ISSN 1557-4989

(C) 2011 Science Publications

\title{
Skin Firming, Skin Smoothing, Skin Blemishes Elimination and Anti-aging Effects of Increased Protein Intake in the Form of Voandzeia hypogeal Seed Meal
}

\author{
Utoh-Nedosa Uchechukwu Anastasia \\ Department of Pharmacology and Toxicology, Faculty of Pharmaceutical Sciences, \\ Nnamdi Azikiwe University, Awka, Anambra state, Nigeria
}

\begin{abstract}
Studies on the effect of excess calorie intake on the human body showed that it resulted in accumulation of excess body fat; the darkening of the skin colour and the development of a bumpy skin. Problem statement: The present study investigated the effects of increased protein intake on the human skin and on body fat. The skin firming, skin smoothing and skin colour lightening effects of Vernonia amygdalina leaf extract has already been established. The anti-obesity, body calming and anti-aging effects of VA leaf extract have also been established. Approach: The effects of increased protein intake (in the form of eating of $100 \mathrm{gm}$ Voandzeia hypogeal seed paste meal two times daily), was tested on the skin, anti-obesity and anti-aging effects of VA leaf extract. The study was done for 10 days. Results: The results of the study showed that Voandzeia subterranean (hypogea) cooked potentiated the skin tightening, skin smoothing, skin colour lightening and the anti-obesity/antiaging effects of VA. Leaf extract. These results show that increased Voandezia hypogeal seed paste meal [increased protein intake has skin tightening/clearing/lightening/Smoothing and antiobesity/anti-aging effects]. They also show that cooked Voandzeia hypogeal seed paste meal has a potentiating effect on the skin and body effects of VA leaf extract. Conclusion: From the findings of this study the author to concludes that increased protein intake potentiated the skin firming/skin Smoothing/skin colour lightening; body calming; anti-obesity and anti-aging effects of Vernonia amygdalina leaf extract. The study also concludes that Voandzeia hypogeal seed meal has skin firming/skin Smoothing/skin colour lightening (clearing); body calming; anti-obesity and anti-aging effects.
\end{abstract}

Key words: Increased protein, skin tightening, leaf extract, calming anti-obesity, skin smoothing, colour lightening, Vernonia amygdalina, paste meal, protein intake

\section{INTRODUCTION}

Many people in the world know that proteins are body building foods. However, a large number of people do not know the far reaching effects of adequate protein intake on the health and looks of an individual. The aim of this research study was identify some physically visible effects of protein intake on the human body.

The nutritional potential of a number of raw tropical seeds were assessed in a series of feeding trials with rats in which seed lectin reactivity was monitored. Abelmoschus esculantus, Chenopodium quinoa, Delonix regia, Phaseolus calcaratus, Phaseolus lathyroides, Parkia biglandulosa, Papeaver somniferum, Sesbania Arabica, Terminalia catappa, Vigna sinensis and Voandzeia subterranea seeds were found to have supported moderate rat growth (Grant et al., 1991). Also five media formulated fromdried cow blood, mineral salts and salts from four species of legumes, were assessed for growth, sporulation and insecticidal properties of Bacillus sphaericus strain 1593. Bacterial powders prepared from broth were assayed against Bacillus Culex quinquefasciatus, Anoppheles gambiae and Aedes aegypti. Good growth and sporulation were obtained with all the media and the highest number of viable cells and spores per milliliter $[8.6 \times 10(8)$ and $8.1 \times 10(8)]$ were obtained in media containing ground seeds of Vigna unguiculata, Voandzeia subterranean and Arachis hypogea ()beta abd Okafor, !983). These two cited examples show that Voandzeia hypogea or subterranean is a good source of protein that can support animal or human growth.

\section{MATERIALS AND METHODS}

Mature red stalked Vernonia amygdalina (bitter leaf) leaves were selected and dried in the shade, 
indoors or in low sunshine. $V$. amygdalina leaf effusion was made by extracting fragments of the dried $V$. amygdalina leaves with two times their own volume of boiling drinking water in a cooking pot.

The VA leaves were extracted fully by stirring them in the boiling water. The VA leaf effusion was then sieved out with a fine meshed sieve and stored in a clean plastic jar with a tight fitting cover.

Treatment: The subject took $33 \times 2$ milliliter cupfuls of the $V$. amygdalina leaf infusion orally, 4 times daily or $33 \mathrm{ml}$ cupfuls of the $V$. amygdalina leaf infusion orally, 8 times daily. The VA leaf extract treatment was taken for one month before the Voandzeia hypogeal meal test. The VA leaf extract treatment was continued during the Voandezia hypogea seed past meal.

Dietary restrictions: The subjects were disallowed consumption of the following foods; lard; vegetable oil; butter/margarine; mayonnaise; grated coconut; bacon; ground nut/peanut butter; nuts like palm nut, coconut, date palm; oil fried foods; oily seeds like mellon seeds, sun flower seeds, peanut seeds; oily fruits like avocado pea, Nigerian pea; oily soups, stews or gravies; oily cooked or prepared meals like salads, bean cakes. and pastries or flour foods like dough nuts, burns, cakes, spaghetti/macaroni, bread; acidic beverages like coffee, tea, cocoa; acidic fruit juices like lime juice, lemon juice, pineapple juice; soft drinks (including malt drinks and carbonated drinks); tobacco or tobacco products; garlic or acidic food spices and condiments; artificial food seasoning (artificial salt or salt substitutes including potash) and alcohol.

Permitted diet and eating behavior: The subject was only permitted to eat meals containing their normal daily requirements of proteins, non-acidic fruits; mineral salts and water. The carbohydrate ration permitted for the subject was only one third of the previously consumed carbohydrates and one tenth of the previously consumed dietary fats and oils. Leafy vegetables were made to replace two thirds of the carbohydrates which the subject previously consumed.

The subject was required to eat only two meals in a day, one in the morning to mid-morning and the second one in the evening/night hours.

The Voandzeia seed paste meal: The Voandzeia seed paste meal consisted of the eating of $100 \mathrm{gm}$ of Voandzeia sutarranea cooked seed paste. Powdered Voandzeia hypogea seed which had been made into a paste with warm water to which palm oil and common salt were added was cooked in white polythene bag wraps.
The subject ate $100 \mathrm{gms}$ of the Voandzeia hypogeal meal two times daily for 10 days in conjunction with the VA leaf extract treatment.

\section{RESULTS}

The results of the study on the physical looks of the subject are shown in the pictures in Fig. 1-3.

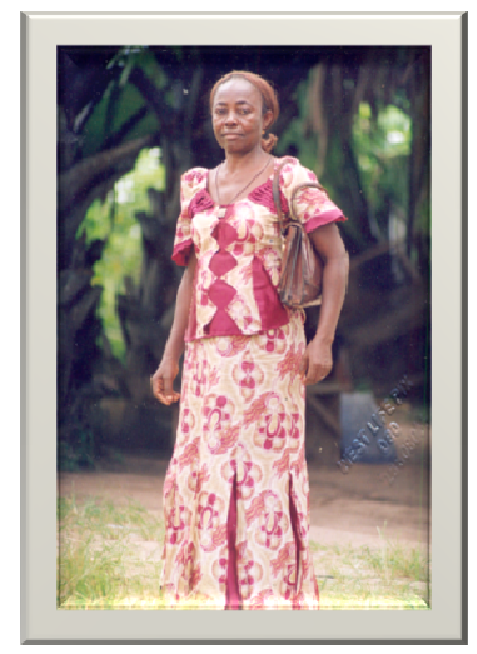

Fig. 1: The subject before the treament with Vernolina amygdalina leaf extract

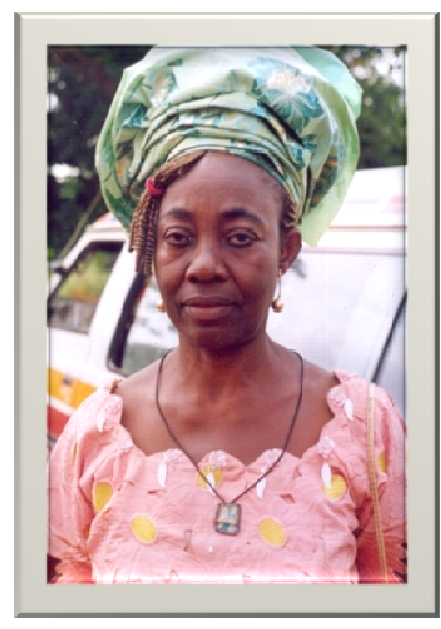

Fig. 2: The subject showing the effect of Vernonia amygdalina treatment which produced the skin firming/skin Smoothing/skin colour lightening; body calmness, elimination of excess body fat and anti-aging effects of Vernolina amygdalina leaf extract 


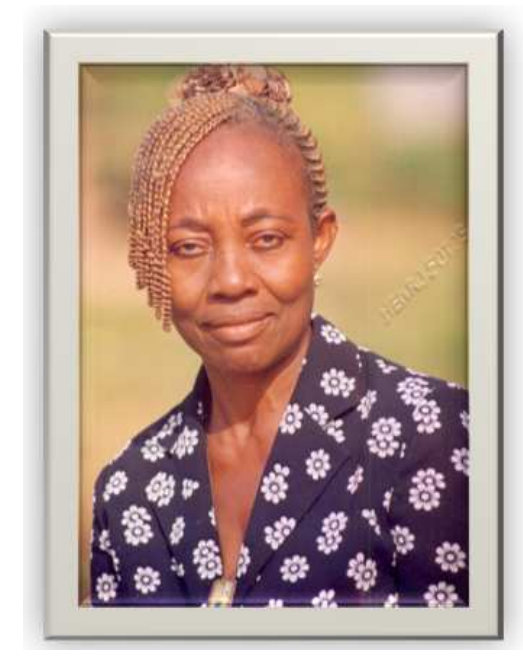

Fig. 3: The subject showing the effect of Vernonia amygdalina treatment potentiated by the effect of 10 days consumption of Voandzeia hypogea seed paste meal which produced potentiated skin firming/skin Smoothing/skin colour lightening; body calmness, elimination of excess body fat and anti-aging effects of vernolina amygdalina leaf extract

\section{DISCUSSION}

A comparism of the subject's skin and body physique shows that the defattening; skin firming/skin Smoothing/skin colour lightening and antiaging effects of VA leaf extract seen in Fig. 2 were potentiated by $V$. hypogeal seed paste meal consumption.

The results of the study suggest that each of Vernonia amygdalina leaf extract and Voandezia subterranean seed paste meal could on its own produce body defattening; skin colour lightening (skin clearing effects); skin tissue tightening; skin Smoothing and anti-aging effects in the order of $V$. amygdalina leaf extract effects > Voandezia hypogeal seed meal.

The skin clearing, skin Smoothing; skin tightening; anti-obesity and anti-aging effects of Voandzeia subterranean or hypogeal obtained in this study is supported by the following submissions of the owner of the European patent EP1174144 on the properties of the extracts of Voandzeia subterranean particularly the protein extracts:

- They have strong nutritive and cellular power

- They have softening and bio-filmogenic effects

- They have cutaneous conditioning and repair effects
- They have anti-wrinkle effects

- They have skin tightening effects

- They have dermal protective and elastic tissue protective effects

- They have anti-irritant, anti- free radical, antipollution, hydrating, anti -UVB photo-protection effects

They have pacifying, anti-proteases, anti- elastases, anti-collagenases, anti-catalase, anti-aging and cutaneous firming effects (Silvano, 2002).

This same author of the sited patent found that Voandzeia subterranean seed extracts have the following advantageous effects on the hair:

- Bio-conditioning effects

- reparative effects

- softening effects

- Vitalizing post application effects on hair and nails (Anastasia, 2011a)

The skin and hair effects noted here by the author of the European patent cited above have been noted in the studies of the present author and some other studies (Obeta and Okafor, 1983; Grant et al., 1991) for Vernonia amygdalina leaf extract (Anastasia, 2011a; Anastasia, 2011b) and with Voandzeia hypogeal seed meal (unpublished findings). The antiobesity and anti-aging effects of Vernonia amygdalina have also been demonstrated (Anastasia et al., 2011; Anastasia, 2010).

\section{CONCLUSION}

The findings of this study enable the author to conclude that increased protein intake potentiated the skin firming/skin Smoothing/skin colour lightening; body calming; anti-obesity and anti-aging effects of Vernonia amygdalina leaf extract. The study also concludes that Voandzeia hypogeal seed meal has skin firming/skin Smoothing/skin colour lightening/skinclearing; body calming; anti-obesity and anti-aging effects.

\section{REFERENCES}

Anastasia, U.N.U., 2010. Anti-carcinoma, anti-obesity, antidiabetic and immune defence effects of Vernonia amygdalina leaf extract and leaf powder, in two human cancer patients. Am. J. Immunol., 6: 50-53. DOI: 10.3844/ajisp.2010.50.53 
Anastasia, U.N.U., 2011a. Inhibition of skin colour darkening (skin clearing and lightening); skin firming; body calming and body vitalizing effects of vernonia amygdalina leaf extract. Am. J. Pharmacol. Toxicol., 6: 33-36. DOI: 10.3844/ajptsp.2011.33.36

Anastasia, U.N.U., 2011b. Normal hair colour, hair texture, hair form, hair lusture and hair condition restoration effects of aqueous Vernonia amygdalina leaf extract. Inventi J.

Anastasia, U.N.U., A.C. Fred, N.K. Stanislaus and O.U. Anthonia, 2011. Excess body fat elimination (antiobesity) effects of Vernonia Amygdalina leaf extract. Am. J. Pharmacol. Toxicol., 6: 55-58. DOI: 10.3844/ajptsp.2011.55.58
Grant, G., L.J. More, N.H. McKenzie, P.M. Dorward and J.C. Stewart et al., 1991. A survey of the nutritional and haemagglutination properties of several tropical seeds. Livestock Res. Rural Dev.

Obeta, J.A. and N. Okafor, 1983. Production of bacillus sphaericus strain 1593 primary powder on media made from locally obtainable Nigerian agricultural products. Can. J. Microbiol., 29: 704-709. PMID: 6883226

Silvano, P., 2002. Dry Extract rich in isoflavones and process of preparation: European patent application EP1174144. FPO. 